\title{
Da Cibernética à Autopoiesis: continuidades e descontinuidades
}

\section{From Cybernetics to Autopoiesis: continuties and descontinuities}

\begin{abstract}
Resumo: O artigo tem por finalidade refletir como a teoria da autopoiesis foi influenciada pela Cibernética, e como ambas contribuíram para o esclarecimento da interacção entre os fenómenos de aprendizagem e os de educação. A metodologia utilizada é de tipo hermenêutica. Discute-se o surgimento da Cibernética. As três cibernéticas até aos anos 80-90. Cibernética e Biologia. As continuidades e descontinuidades entre a autopoiesis biológica e a auto-regulação cibernética. Aprendizagem e auto-produção de sentido, via acopulamentos estruturais. Observação e Educação. Em conclusão evidencia-se que existem incongruências lógicas e epistémicas entre o estudo da auto-regulação cibernética e o das autopoiesis biológicas; que a conceitualização da cibernética de $2^{a}$ ordem foi especialmente importante para a compreensão da dimensão observacional na teoria autopoiética, da qual decorre a educação; que os processos de educação só produzem aprendizagem efetiva quando os educadores e/ou conteúdos informacionais possibilitam um reforço, uma criação, ou uma flexibilização de sentido autopoiético do educando.
\end{abstract}

Palavras-chave: Autopoiesis. Cibernética. Aprendizagem. Educação.

Abstract: The purpose of this article is to reflect how the autopoiesis theory was influenced by the cybernetics and as both contributed to the explanation of the interaction between learning and education phenomenon. We used hermeneutical methodology. We discuss the cybernetic's emergence. The three cybernetics until 80-90. Cybernetics and biology. Continuities and discontinuities between the biological autopoiesis and the cybernetic self-regulation. Learning, individual's and community's self production of meaning, through structural couplings. Observation and Education. In conclusion, we point logical and epistemic incongruities between the study of cybernetic self-regulation and the one of the biological autopoiesis; that some concepts of cybernetics of $2^{\text {nd }}$ order were especially important for the understanding of the observational dimension in the autopoiesis theory of which elapses education; that education processes only produce effective learning when the educators and/or informational contents make possible a reinforcement, a creation, or a flexiblization of the other person's autopoietic meaning.

Keywords: Autopoiesis. Cybernetics. Learning. Education.

OLIVEIRA, Clara Costa. Da Cibernética à Autopoiesis: continuidades e descontinuidades. Informática na Educação: teoria \& prática, Porto Alegre, v. 12, n. 2, p. 23-34, jul./ dez. 2009.

\author{
Clara Costa Oliveira \\ Universidade do Minho
}

\section{Surgimento da Cibernética}

A Cibernética surgiu na história da humanidade apenas no século XX e quem percorra toda a vida ao longo do século atual pode muito bem nunca encontrar o seu nome, dado muitos acreditarem que a sua missão e sua função foram já substituídas pelas Ciências da Computação.

Seja como for, a releitura das obras dos pioneiros da Cibernética deixam-me sempre extasiada face ao mundo que naquelas páginas aqueles pensadores, imaginavam, criavam, e fabulavam...e que se tornou real! E, no entanto, como tantas vezes, tudo começou por causa da guerra.

Com a II Guerra Mundial, tornara-se claro que a investigação científica deveria manter-se em estreita ligação com o mundo do armamento, não só para criar novas máquinas para matar, mas sobretudo para inventar máquinas que destruíssem máquinas de efeito devastador. Muitos dos cientistas (além de filósofos, compositores, etc) de origem austríaca e alemã (sobretudo os que eram simultaneamente judeus) tinham fugido para os EUA; vários deles foram acolhidos pela Companhia Bell, pioneira dos telefones, ou seja, com um papel fundamental na comunicação humana. Esta experiência de 
aliar o saber electrónico à comunicação entre pessoas, entre povos, é algo determinante para o surgimento... da Cibernética. "Nous avons décidé de désigner le champ entier de la théorie du controle et de la communication, aussi bien dans les machines que chez les êtres vivants, sous le nom de Cybernétique [ ... ]" (WIENER, 1971, p. 12); de notar que a palavra remete etimologicamente para aquele que controla, como um piloto.

Por volta de 1943, um grupo de investigadores, coordenados por Arthur Rosenbleuth e Norbert Wiener, criaram a Cibernética (embora o termo já tivesse sido referenciado por Ampère, por exemplo), para estudarem os mecanismos de regulação e de auto-regulação em máquinas e nos seres vivos, a comunicação e a construção de máquinas que criassem comunicação, ou a incrementassem. Naquela altura, aquele tipo de pesquisa era muito importante para conseguir perceber como funcionavam armas programadas, armas de detonação programada à distância (como mísseis) ou armas auto-programadas.

A questão da comunicação foi-lhes influenciada pela teoria da informação de Claude Shannon, que abordava a quantidade de informação recorrendo aos conhecimentos de termodinâmica, nomeadamente a de L. Boltzmann (OLIVEIRA, 2009). O que é muito importante perceber nas concepções e experiências de Shannon é que a quantidade de informação transmitida em vias comunicativas sujeitas a ruído não se relaciona com a sua significação. Para Shannon, informação correspondia à medida de várias possibilidades de escolha que uma mensagem pode ser seleccionada por um sistema. O famoso 1 o teorema de Shannon estabelece um paralelismo entre a medição de redundância (aspectos ruidosos) num processo comunicativo - função H (o exemplo clássico para se compreender a teoria de Shannon é a comunicação por telex) e a medição de entropia num sistema físico aberto ou fechado - função $S$ (obviamente que a entropia, em termodinâmica, também não se preocupa com significações, pois estamos na área física que estuda fenómenos térmicos e gasosos).

Explicitemos melhor esta questão: para Shannon, informação era o que se conseguia obter pela quantidade com que um signo ocorre dentro de uma mensagem, numa via de comunicação mais ou menos ruidosa. Ele não negava que a mensagem tinha uma significação, nem tampouco que esse significado pudesse ser aferido por bits informativos muito menos frequentes na mensagem do que aqueles que ocorriam mais vezes; no entanto, ele pretendia aferir a informação quantitativa que se podia obter em mensagens, ignorando o seu eventual significado, enquanto mensagem. Os estudos de Shannon foram muito importantes no campo da zoologia, por exemplo, especialmente no estudo dos cânticos dos pássaros e alguma da investigação que primeiramente se fez em Palo Alto era explicitamente centrada em Shannon, dado que existem transcrições de comunicação cinestésica e não verbal de terapeutas, como G. Bateson, acentuando-se a informação que se obtinha na sequência comunicativa, pela repetição de determinados gestos, colocação de corpo, etc.

A importância de Shannon para a Cibernética tem então a ver, antes de mais nada, em ter fornecido um teorema que permite medir a quantidade de informação entrada numa máquina (construída pelos seres humanos); conseguimos também com esse instrumento matemático aferir quais dessas entradas são mais ou menos redundantes; a função $\mathrm{H}$ proporciona-nos prever o programa de respostas com que a máquina lidará com essas redundâncias, indicando as possíveis saídas.

Logo no ano seguinte após a publicação de seu famoso artigo, A Mathematical Theory of Communication (1948), Shannon publica um livro em parceria com Warren Weaver onde de novo estas questões são colocadas, mas com um posicionamento diferenciado por parte de Weaver. Com efeito, este matemático norteamericano faz questão de distinguir três níveis de produção de informação: 1- a interação de sinais dentro de um canal comunicacional (o nível de Shannon); 2- nível do emissor que emite sinais informacionais por meio de um, ou vários, canais comunicacionais; 3- nível do receptor dos sinais emitidos pelo emissor e recebidos por um, ou mais, canais de comunicação. Estes dois últimos níveis acarretam consigo as dimensões da compreensão (codificação/ descodificação) dos sinais, dos seus sentidos possíveis e da eficácia na transmissão desses sinais. Todos estes elementos nos dirão se há, ou não, uma mensagem. É que pode haver comunicação apenas com informação, em sentido shannoniano, e sem mensagem. 


\subsection{BCL - Biological Computer Laboratory (1958-1976)}

Este era pois o tipo de questões com que os pioneiros da Cibernética se encantavam e a sua construção maquínica no BCL tinha-as presentes. Mas o fato de estes homens vindos da Matemática, Física e Engenharia eletrônica terem apelidado o seu laboratório como biológico deve-nos fazer pensar um pouco. A principal razão para tal fato é que muitos deles tinham estudado processamento informacional em sistemas vivos; tal acontecera no MIT, nomeadamente com o então jovem Humberto Maturana que investigava com Wiener - e McCulloch, entre outros - o processamento informacional da retina de rãs. O que este tipo de estudos indicava era que a informação processava-se de modo diferente do modo como era processada nos sistemas físicos. A diferença parecia residir em que, de algum modo, os seres vivos construíam a informação que emitiam por processos de auto-regulação interna. Assim, por exemplo, no estudo da cor na percepção visual percebia-se que ela emergia na relação entre a estrutura interna do olho para dentro (portanto, no seu enraizamento cerebral) com a retina (exposta a factores ambientais, como a luz).

Perceber que tipo de processos eram esses, conseguir descrevê-los e posteriormente construir máquinas que os conseguissem empreender era o principal sonho dos que trabalhavam no BCL, em Illinois. Quem o terá perseguido, dentro do $\mathrm{BCL}$, com mais persistência talvez tenha sido Heinz von Foerster.

Enquanto Shannon tentara aferir valores positivos informacionais pela anulação dos aspectos ruidosos (que são os redundantes, no caso do telex, por exemplo), von Foerster (1960) vai tomar como desafio o não controle dos aspectos ruidosos, deixando-os atuar.

Criou um modelo qualitativo, com cubos magnetizados em mais que uma face. Colocou-o dentro de uma caixa, fechou-a, abanou-a e deixou rolar os cubos. Que configuração tomaram os cubos para um observador que desconheça que os cubos estão magnetizados? Em princípio, considerará que eles estão desordenados (ou seja, aplicando Shannon, a quantidade de signos é muita, mas é totalmente redundante, pelo que a informação é praticamente nula).
Von Foerster ( 1960) fez em seguida a mesma experiência mas com os cubos magnetizados apenas numa das faces. O resultado foi uma configuração de cubos ordenada, dado que haverá cortes de redundância fornecida pelas configurações obtidas com as faces dos cubos magnetizados; consegue-se um conjunto de cubos que constroem algo com sentido para um observador.

As lições epistemológicas desta experiência de von Foerster são sobretudo duas: 1- quem atribui sentido ao mundo é um observador, e o sentido depende do contexto observacional em que ele se encontra (quais as variáveis informacionais que ele possui, e qual o saber que ele detém, sobre aquilo que observa; 2- a aleatoriedade (o lançamento dos dados ao acaso) pode produzir produtos ordenados (princípio de order from noise de von Foerster).

Nenhuma destas questões eram novas, pois ambas tinham sido já enunciadas e desenvolvidas no âmbito da Física, por Einstein e Schrodinger, por exemplo, mas o impacto das concepções de von Foerster foi muito grande na Biologia e (restantes) ciências humanas, talvez por na época a própria Biologia estar mais focalizada nos modelos interpretativos que advinham da teoria da informação do que das explicações astrofísicas, quânticas e termodinâmicas. Voltando à Cibernética, o que von Foerster (1984) considerava importante no seu modelo era exatamente ele indicar-nos que os sistemas vivos poderiam eventualmente atuar como os cubos magnetizados, e nós é que não os sabíamos magnetizados, continuando na metáfora. Daí a importância de se conseguir construir máquinas que conseguissem criar ordem a partir de desordem, de redundância informacional. À magnetização dos cubos ele começou a apelidar, auto-organização e nunca a equipe do BCL conseguiu construir uma máquina que se auto-organizasse de um modo tão complexo como a mais básica da estrutura do ser vivo, a célula.

O fato de ele ter salientado a importância do observador (latu sensu, e não só no que respeita à dimensão visual) na atribuição da informação fornecida por um sistema comunicacional abriu as portas para aquilo que ficou conhecido como a cibernética de $2 \underline{a}$ ordem 


\subsection{A Cibernética de 2a Ordem}

Assim, passou-se a convencionar que a cibernética de $1^{\mathfrak{a}}$ ordem se referia à tentativa de construção de máquinas que permitissem criar e transformar informação, enquanto a da $2^{\text {a }}$ ordem se dedicava a estudar a possibilidade de criar máquinas que simulassem a complexidade humana. Ainda que o propósito possa parecer o mesmo, von Foerster (entre outros) veio claramente salientar que havia diferenças a assinalar, como vimos.

[ . . ] I may briefly mention the two different schools of thought associated with this problem, namely the one which considers energy flow and signal flow as strongly linked, single-chair affair (i.e. the message carries also the food, or, if you wish, signal and food are synonymous) while the other view-point carefully separates these two, although there exists in this theory a significant interdependence between signal flow and energy availability. I consider that I do belong to the latter school of thought [ . . . ] (VON FOERSTER, 1960, p. 33-34)

No âmbito desta linhagem, temos também que salientar que Wiener sempre considerou que a informação, em sistemas complexos, não poderia ser concebida como sendo apenas apreendida. A dimensão de inter-constituição sistema complexo-nicho (nicho, que aos olhos de um observador, é um meio) era algo por si defendida e que colocava questões inovadoras quanto à compreensão da memória e da aprendizagem, e da comunicação humana (linguagens articuladas). É neste âmbito que ele distingue acoplamentos de tipo energético dos de índole informativa, dado que os primeiros originam sistemas comunicacionais que se constituem, e se mantêm, pelas leis de regulação dos sistemas parciais entre si. Os acoplamentos informacionais, no entanto, referem-se a trocas informacionais de sistemas subordinados à regulação de um sistema maior. $^{1}$

No que se refere à memória, não podemos deixar de mencionar as contribuições de Ashby, que a considerava estreitamente ligada à dimensão observacional, pois é um observador, ou um auto-observador, que constrói uma representação mental da atuação

1 Ter em conta nota 2. passada do organismo observado. Ele registou que os sistemas auto-organizados tendem a conservar processos de adaptação viabilizados, e a reproduzi-los, pelo que a comunicação entre seres vivos constitui-se como fator mais importante que conteúdos informacionais.

Split the equilibrium in two, call one part 'organism' and the other part 'environment': You will find that this 'organism' is peculiarly able to survive against the disturbance from this 'environment', The degree of adaptation and complexity that this organism can develop is bounded only by the size of the whole system and by the time over which is allowed to progress towards equilibrium [ . . . ] (ASHBY, 1984, p. 258).

Outraquestãolevantadaporesteinvestigador foi sobre se os mecanismos de aprendizagem em sistemas auto-organizados possuíam, ou não, uma dimensão auto-avaliadora (o organismo avalia o que é bom, ou mau, para si?); esta questão deve ser, ou não, abordada de modo diferente se o sistema em causa tiver capacidade (auto)observacional? Este tipo de perguntas era muito frequente no $B C L$, onde um dos seus mais conhecidos investigadores, Gordon Pask (1970) criou o axioma de incerteza observacional, que estipula a não existência de um isomorfismo entre o funcionamento de um sistema observado e a sua descrição observacional (ele ligou este teorema à teoria dos jogos de von Neumann). Estes são apenas alguns dos imensos contributos da cibernética da $2^{a}$ ordem para a compreensão do mundo vivo.

\subsection{Cognitivismo Cibernético, I A e Neo-Conexionismo}

Abordaremos brevemente estas linhagens teóricas, orientando-as em exclusivo para o propósito do artigo: identificar continuidades e rupturas entre o mundo das linhagens informáticas e a teoria da autopoiesis no que respeita aos fenómenos de aprendizagem e aos de educação.

A partir dos anos 50 do século passado, é a corrente cognitivista que impera no mundo cibernético, tendo-lhe sido associada, com alguma falta de rigor epistemológico, a Inteligência Artificial (IA). A correntecognitivista teve (tem) grande peso na Psicologia e Biologia, tendo influenciado (e vice-versa) o cognitivismo cibernético. Tem evoluído por 
caminhos algo diferentes entre si e o que aqui descrevemos prende-se sobretudo com as suas concepções nos anos 50-80, não pretendendo de forma alguma esgotar tal problemática com esta breve descrição interpretativa.

A cognição é descrita como sendo um tipo de cálculo logarítmico que um sistema efetua, articulando as suas representações internas com aquilo que ele pretende obter face a questões que tem que resolver. $\mathrm{O}$ que queremos aqui ressaltar não é tanto a dimensão teleológica que esta corrente possui, mas o fato de ela ter que se relacionar com um determinismo representacional, já que as representações internas são como que fórmulas que expressam corretamente signos base formal de tipo inato. Essa linguagem básica formal inclui regras morfológicas e sintácticas precisas. Garante-se assim uma adequação das representações ao mundo representado, dado o paralelismo formal (do mesmo tipo que o existente no interior de um sistema de lógica formal) entre a sintaxe (a representação enquanto tal, como signo, por exemplo) e a semântica do signo, o seu significado. Alguns dos nomes mais importantes desta corrente são Chomsky, Minsky, J ohn e Ray McCarthy.

Notemos que a questão da regulação da informação é aqui tratada de um modo quase perfeito, logicamente falando, dado que ela resulta de atualizações contínuas de programação existente a priori. Aqui não há lugar para a possibilidade de a ordem emergir do ruído, nem tampouco existe necessidade de pensar no observador, no que respeita aos significados da informação.

Esta crença na similitude entre cálculo proposicional lógico-formal (puramente dedutivo) e a atuação cerebral considerada inteligente, está na base da IA (e dos famosos testes de QI ).

Neste conexionismo artificial, criaram-se máquinas que conseguem resolver problemas formulados por equações, e as suas RNA possuem todas um programa, onde está armazenado, o mais claramente possível, a sequência de ordens a executar. Atingiu o seu apogeu por volta dos anos 80, mais concretamente com o ciclo de conferências de Hopfield, entre 1982 e 1986.

Minsky (1969) vai apelidar o projeto do $B C L$ de época romântica (onde se construíram máquinas que se tentavam assemelhar ao funcionamento dos seres vivos, como o
Perceptão e a Adaline), e ele é considerado como o precursor da I A no âmbito da engenharia electrónica.

Emergindo do cognitivismo cibernético, a IA apostou pois na construção de máquinas (de tipo digital e de tipo analógico ${ }^{2}$ ) que fossem capazes de revelar inteligência, isto é, de processarem representações internas. As RNA (redes neuronais artificiais) fazem parte de uma fase mais avançada desse projecto, e os engenheiros da neurocomputação mais ortodoxos fazem questão de recusar qualquer ligação de RNA com as redes neuronais naturais. Hoje existe um número imenso de RNA, entre elas RNA auto-organizadas - a partir do trabalho de Kohonen (1982) e as estocásticas - onde se inclui “[ . . . ] a máquina de Boltzmann, de Hinton e Sejnowski (OLIVEIRA, 1999, p. 110).

No entanto, um grupo de investigadores transdisiciplinar (onde se incluíram os biólogos Henri Atlan e Francisco Varela e um dos investigadores do BCL, Gordon Pask) decidiu centrar-se na aprendizagem de RNA face a perturbações aleatórias, retomando algumas das questões em que se focalizava o $B C L$, mas num contexto muito desenvolvido, do ponto de vista técnico-computacional. A este grupo, a história da ciência cognitiva apelidou-o de neoconexionistas, e dele derivam os enatistas e os emergentistas. Os primeiros ensaiaram a criação de sistemas resultantes de componentes aleatoriamente distribuídos numa RNA, tentando estabelecer ligações possíveis com a construção semântica nos seres vivos. A segunda decorre desta, tendo sido muito utilizada na compreensão da diferença de nível existente entre mente e cérebro, já que a produção da mente não corresponde à

2 As máquinas de tipo digital da época funcionavam com um número reduzido de variáveis; as suas saídas eram muito precisas e fiáveis, ainda que sem margem de novidade informacional; um exemplo é uma máquina de calcular com apenas as 4 operações básicas. As de tipo analógico eram aquelas que possuíam uma multiplicidade muito grande de variáveis informacionais; estas máquinas conseguiam produzir muitos outputs informativos mas muito pouco fiáveis. A internet assenta numa estrutura de tipo analógico. É de salientar que estes conceitos são usados no atual mundo computacional de modo diferente do mencionado, dada a incrível evolução que se verifica nesta área. G. Bateson (1979) utilizou estes conceitos para se referir às linguagens articuladas humanas (verbais e escritas) e às cinestésicas e não verbais, respectivamente. 
soma dos processos cerebrais, nem tampouco dos seus componentes (dizer que a mente possui componente é algo, no mínimo, bizarro) (VARELA; THOMPSON; ROSCH, 1991).

\section{Cibernética e Biologia}

Como já tivemos oportunidade de ir constatando pela leitura deste artigo, a relação da Cibernética com a Biologia não foi nunca simples e linear. Proponho-meagora destrinchar um pouco mais esta relação intrínseca, ainda que polêmica, começando por fazer uma breve referência à Embriologia e à Biologia molecular para depois nos focalizarmos na Teoria da Autopoiesis.

\subsection{A Embriologia}

A embriologia, na primeira metade do século $X X$, procurou estabelecer princípios explanatórios baseando-se na termodinâmica, sobretudo nos estudos de Boltzmann e Prigogine (com a sua teoria das estruturas dissipativas), bem como nas pesquisas de filósofos como Henri Bergson e Whitehead. A quem esteja menos familiarizado com a história da Biologia, esta ligação (de Weiss e Needham, entre outros) pode parecer estranha, mas resulta de algo muito peculiar: a embriologia emergira como área de ponta dentro da Biologia após a árdua derrota das teorias criacionistas face ao sucesso das concepções evolucionistas. Estudar embriões (humanos e de outras espécies) constituía o aprofundamento do evolucionismo ao nível mais micro que era então possível. Destes anos de poderio embriológico, resultaram dados extraordinários, como o fato de os embriões só poderem ser reconhecidos como pertencendo a determinada espécie a partir de um determinado grau de desenvolvimento morfológico (OLIVEIRA, 1999).

Ser evolucionista significa não fora ser vitalista, que conota as teorias criacionistas e as de geração espontânea (entre outras) ao vitalismo aristotélico-cristão, pelo menos naquela época. Assim, o que o vitalismo pressupõe, em Biologia, é a existência de uma entidade exterior (de tipo transcendental, usualmente) que funciona como princípio explanatório da capacidade auto-organizadora dos seres vivos. Ora bem, era este tipo de explicação formal que a Cibernética proporcionava à Biologia: era possível construir máquinas de grande nível de complexidade (aproximando-se inclusive da complexidade humana), desde que fossem programadas por alguém exterior à própria máquina. A causalidade de tipo retroactivo oferecido pela Cibernética exigia a existência de um programador da máquina, o que afastou os embriologistas da Cibernética.

No entanto, os embriologistas tinham noção de que os princípios explanatórios típicos do mecanicismo clássico (newtoniano), como a explicação formal (ou linear), não Ihes serviam, dado que o desenvolvimento dos embriões era muito variado e bastante imprevisível; quando um estado de um embrião acontece (e.g.: gástrula) não é possível saber a que tipo de órgão (ou tecido) ele dará origem.

É pois face a este impasse conceitual que vários embriologistas procuram ajuda em outras áreas, como vimos; alguns deles esperavam encontrar um organizador biológico básico, que explicaria o desenvolvimento morfogenético dos seres vivos. A busca desta substância base organizadora de tipo físicoquímica foi levada a cabo por investigadores da escola de Bruxelas (liderados por Dalcq e Pasteels) e nunca foi encontrada.

\subsection{A Biologia Molecular}

Sobretudo a partir dos anos 50, o cenário da Biologia altera-se profundamente. O físico Francis Crick foi um dos pais da biologia molecular, ao aplicar à biologia bacteriana à teoria da informação. Três fatores têm que ser imediatamente identificados: primeiro, Crick apoiou-se no livro de Schrodinger What is Life?, onde se defendia que a ordem biológica era de um tipo diferente da ordem termodinâmica; segundo, Crick utiliza a teoria da Shannon, mas misturando-a com a de Weaver, ou seja, misturando a sintaxe com a semântica; terceiro, ao fazê-lo, ignora totalmente a dimensão observacional, quer do emissor, quer do receptor, tendo como principal consequência que a interpretação do cientista sobre a informação produzida é considerada nula. A descrição observacional corresponde isomorficamente ao que onticamente ocorre no objecto de estudo observado. 
Com o estabelecimento da estrutura e da função do ADN, considerou-se que ele constitui a substância explanatória de características transmitidas hereditariamente, de modo geracional. A relação entre a sequência de bases no DNA e a sequência correspondente da aminoácidos, nas proteínas, corresponde ao código genético. As proteínas exprimem pois a informação onde seria mantida a sucessão de acontecimentos, raros e aleatórios, que constituíram as mutações favoráveis à espécie (OLIVEIRA, 1999).

A teoria da informação aplicada à Biologia constitui-se como princípio explanatório realmente extraordinário pois conseguiu fundir o evolucionismo com a genética de Mendel. A partir de então, temos cada vez mais pessoas no mundo convencidas que os que as identifica como seres vivos (e até humanos) é o seu DNA, relações de substâncias puramente físico-químicas, havendo poucos que pensem por que é que o DNA do Tutankamon, que foi colhido no seu sarcófago passados milhares de anos, é o DNA de alguém morto, e o nosso DNA é o de alguém vivo? O que distingue o DNA de um ser vivo do de um cadáver tornado mero pó? Estas perguntas não incomodam os biólogos moleculares, assim denominados, por acreditarem que a explicação de tudo quanto é vivo e humano (como a ética, por exemplo) caminha largos passos para ser demonstrado emergir da interacção molecular intra-celular.

Neste contexto, o genótipo surge como a fonte ordenatória de cada ontogenia face às perturbações a que cada indivíduo vai estando sujeito. O carácter determinístico do genótipo garante a realização do projecto teleonómico da espécie, ou seja, como a manutenção da espécie surge como fio orientador da evolução filogenética, essa finalidade é garantida pelo genótipo, em termos ontogénicos. O meio apenas pode acionar, ou inibir, condutas possíveis de ocorrer pré-programadas, recorrendo-se pois claramente à metáfora cibernética, mas evitando a questão vitalista, ao assumir como programador o princípio de optimização da espécie, de origem biológica, e não transcendente. “O 'programa genético' é na realidade um 'invólucro genético', um conjunto hierarquizado de subprogramas, dos quais só alguns são revelados em função das condições iniciais e das interacções com o ambiente" (STENGERS; PRIGOGINE, 1993, p. 117).
Daí se afirmar, epistemologicamente, que o evolucionismo possui uma vertente teleonómica, ou seja, o princípio explanatório é de tipo a priori (a manutenção da espécie pela sua optimização), mas utilizando-o como se ele fosse ontologizado fisicamente, em vez de ser um princípio explanatório a priori criado por observador, ou atribuído a uma outra entidade transcendente ao mundo físico-químico do qual emerge o vivo (o que o tornaria um princípio teleológico), mantendo-nos sempre na lógica desta corrente atualmente paradigmática da Biologia (MONOD, 1970, ATLAN, 1979).

A partir dos meados dos anos 70,à biologia molecular começam a ser feitas muitas críticas, sobretudo no que respeita às explicações que pretende fornecer de fenômenos biológicos mais complexos. Surgem novas teorias - como a da autopoiesis, em 1972 - , ganham relevo outras - como a de Atlan (1972) - e ressurgem outros domínios da Biologia, como a Embriologia. Destaco aqui Conrad Waddington que, desde 1947, utilizava o conceito epigenético para definir o processo com que os fenótipos atuam na selecção da informação genética disponível nos genótipos, optimizando as ontogenias dos organismos com as perturbações ambientais. Waddington direciona então a Biologia - e acaba por o conseguir mesmo em alguns sectores da biologia molecular - para a sua profunda conectividade com o meio, diminuindo a carga hereditária que os biólogos moleculares mais ortodoxos ainda defendem (ATLAN, 1979).

\subsection{A Teoria da Autopoiesis}

A primeira obra de Maturana foi publicada em 1972, numa edição limitada, em parceria com o seu aluno F. Varela, e resultava do grupo de pesquisa coordenado pelo mestre, e onde outros pesquisadores estavam também integrados - sobretudo ao nível laboratorial De Maquinas y Seres Vivos (traduzida, mas com um acrescento assinalado, para Autopoiesis and Cognition, em 1980). Contém toda a teoria biológica da autopoiesis, e dela sobretudo me servirei aqui, pois muitas das obras posteriores destes autores estabelecem pontes com outras áreas, sobretudo ao nível das entrevistas que foram feitas a Humberto e Francisco.

Antes de mais nada, começo por assinalar que a obra se assume como mecanicista, algo que tem sido ignorado por vários autores das ciências sociais; ora bem, trata-se de 
uma obra de biologia e, nesse contexto, ser mecanicista significa não ser vitalista (como acima expliquei); o mecanicismo em Biologia não corresponde epistemologicamente ao mecanicismo moderno. Biologicamente, significa que (tal como é mencionado na obra) se defende que as explicações fornecidas para a ocorrência e funcionamento de fenômenos biológicos só podem recorrer a componentes e processos físico-químicos, e seus níveis de complexidade, sem recurso a qualquer entidade que Ihes seja transcendente ou transcendental. Mas os seres vivos são máquinas de tipo clássico, com funcionamentos causais formais, e demais características do mecanicismo newtoniano? Não, embora essas máquinas existam; são as construídas pelos seres humanos e são de tipo alopoiético.

As máquinas vivas são assim definidas por serem capazes de auto-produzirem os componentes e processos que precisam para surgirem, para se manterem e para se complexificarem continuamente, ou seja, são máquinas autopoiéticas (poiesis significa produzir). Essa auto-produção não requer senão elementos físico-químicos e processos auto-produzidos que as mantêm vivas e daí serem máquinas, mas autopoiéticas. “Nuestro enfoque será mecanicista: no se aducirán fuerzas ni princípios que no se encuentren en el universo físico" (MATURANA; VARELA, 1972, p. 12) Caracterizam-se por serem fechadas informacionalmente ao nível organizacional, ainda que abertas ao nível estrutural, sendo que este se subordina àquele.

Um sistema fechado distingue-se de sistemas isolados (que são solipsistas, e dos quais os autores da autopoiesis se demarcam claramente) e dos sistemas abertos. Os fechados não trocam matéria directamente com os nichos (ou meios, observacionalmente falando), enquanto os abertos assim o permitem. O que torna a teoria da autopoiesis tão interessante é exatamente este carácter ambivalente na descrição do funcionamento dos seres vivos, e tão confuso para quem está habituado a mover-se em modelos epistemologicamente dualistas (no que respeita à origem, natureza e limites do conhecimento) . Por defenderem uma ambivalência contínua entre a dimensão fechada e aberta (ainda que a última subordinada à primeira) é que estes autores são considerados como se movendo no paradigma da complexidade - enunciado formalmente por Morin (1990) - , recusando uma síntese dialética, em termos hegelianos (OLIVEI RA, 2003).

A recusa obsessiva de Humberto Maturana em utilizar a teoria da informação na teoria por si construída - ou mesmo conceitos aparentemente tão inofensivos como informação - deriva da sua repugnância face à deturpação que a biologia molecular empreendeu da teoria de Shannon (1948) o mesmo posicionamento, mas mais leve, verifica-se nas obras do biólogo Henri Atlan; a aproximação de Varela à linhagem das RNA, acima descrita constituiu, aliás, uma das principais causas de afastamento teórico dos autores da teoria da autopoiesis. Note-se que a definição de sistemas vem, de base, da termodinâmica, muito antes de von Bertalanffy (1950) a divulgar - e a criar de modo mais complexo e alargado.

Assim, o que caracteriza as máquinas autopoiéticas com organização fechada e estrutura aberta é, antes de mais, a sua capacidade em se fazerem unidades, de se constituírem como sistemas sem intervenção de nenhum programador externo - o que nenhuma máquina cibernética consegue - ; nelas, a interação que a estrutura, como as membranas celulares, possuem com os nichos é metabolizada e integrada (ou rejeitada) na organização do organismo vivo em função de uma atuação selectiva organizacional - compare-se o conceito organização autopoiética com o padrão de G. Bateson (1972) e compreenderemos melhor esta influência assumida pelos cientistas envolvidos (BATESON, 1972). No entanto, essa atuação selectiva não é determinada a priori, mas antes se vai constituindo ao longo da ontogenia do organismo, o que afasta esta teoria da influência do cognitivismo cibernético.

Organismos vivos saudáveis seleccionam as perturbações a que as estruturas os podem sujeitar. Quando não o conseguem fazer temporariamente, adoecem; quando deixam de o conseguir fazer, morrem. O sistema nervoso não capta informações; ele especifica as configurações metabolizadas pela estrutura do meio-nicho que são perturbações, especificando também as mudanças que elas podem provocar no organismo. É a atuação da organização que assegura a auto-regulação de toda a complexidade de um ser vivo e Maturana sempre teve a preocupação de a justificar, 
enquanto biólogo, mas também enquanto colaborador do BCL. A recusa de Maturana face à utilização da teoria da informação é tão forte que ele defende que todo o funcionamento biológico deve recorrer apenas aos princípios biológicos que ele criou, sabendo complexificálos ao nível de todas as suas consequências. Daí que nos seus textos, desde aqueles sobre neurofisiologia da observação até aqueles sobre a moral humana, nunca seja utilizada qualquer metáfora informacional.

Existem muitos investigadores a usar a teoria da autopoiesis para a compreensão de mundos construídos pelos humanos, e tal é legítimo desde que não nos esqueçamos que a utilização da teoria da autopoiesis não pode nunca ser desvinculada da dimensão biológica implícita em qualquer atividade humana.

Uma das maiores contribuições que esta teoria proporcionou na Biologia, e na epistemologia em geral, foi acentuar a importância dos processos físico-químicos auto-produzidos pelos organismos em vez de salientar a importância de alguns componentes (como causa primeira, como DNA, na Biologia molecular). Se os embriologistas se tivessem focalizado mais no dinamismo processual do que na busca de uma substância base autoorganizadora, talvez a biologia molecular nunca viesse a ocupar tanto poder.

A estrutura aberta dos organismos vivos permite compreender que existe interação com o meio; é ela que leva a que a maioria das teorias biológicas considerem que os seres vivos são sistemas abertos (trocam matéria e energia com o meio). Acontece porém, na teoria da autopoiesis, que como a estrutura se encontra subordinada à organização autopoiética, esta especifica o tipo de matéria e energia que pode ser trocada pela estrutura; ao ser trocada, é imediatamente metabolizada e portanto não há, do ponto de vista interno de qualquer organismo vivo saudável - que significa estar em equilíbrio homeostático em todas as suas dimensões (OLIVEIRA, 2004) -, nem entrada de matéria, nem de energia, puras. Assim, o funcionamento processual das máquinas autopoiéticas é de fora para dentro e de dentro para fora, simultaneamente, com controle destes processos sobre aqueles.

Esta capacidade de selecionar o tipo de perturbação a que se pode estar sujeito está na base da constituição mútua de dois sistemas vivos, observacionalmente falando. De fato, a interconectividade entre sistemas vivos com organizações do mesmo tipo lógico (em linguagem russelliana) permite que ocorram acop(u)lamentos ${ }^{3}$ nas estruturas dos seres vivos.

Cada vez que el comportamento de una o más unidades es tal que hay un domínio en que la conduta de cada una es función de la conduta de las demás, se dice que están acopladas en esse domínio. El acoplamiento surge como resultado de las modificaciones mutuas que las unidades interactuantes sufren, sin perder su identidad, en el transcurso de sus interaciones (MATURANA; VARELA, 1972, P. 66-67).

Do ponto de vista dos organismos acop(u) lados, o que se verifica é a constituição de uma unidade composta, e não a existência de dois sistemas trocando informações, criando uma mensagem de um emissor para um receptor. É sobretudo nesta interação contínua e simultânea - e não sequencial e por etapas, como em Piaget - que os seres vivos aprendem, mas sempre autoregulados pela manutenção autopoiética do sistema, enquanto tal. Em organismos acop(u) lados, uma perturbação num dos sistemas da unidade composta afetará o outro sistema, ainda que com intensidade diferenciada.

O que acabamos de explicitar corresponde ao primeiro princípio da teoria da autopoiesis: aprender é viver; em sistemas vivos de terceira ordem (eg.: humanos, abelhas, formigas)

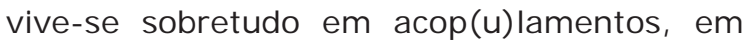
comunidades; são sistemas de terceira ordem por neles a identidade biológica de cada organismo integrar a sua vida comun-itária. Assim, os seres humanos aprendem vivendo nas comunidades com as quais partilham sentidos, construindo mundos.

Note-se que a concepção cognitivista na Cibernética anula a possibilidade da existência de unidades compostas sujeito-nicho dado que as representações internas do sistema determinam o seu funcionamento, impedindo a aprendizagem.

O segundo princípio da teoria autopoiética tudo o que é dito, é dito por um observador

3 Há cerca de 20 anos que investigo e publico sobre a teoria da autopoiesis. Tenho utilizado as palavras acopulamento e acoplamento, em vez de apenas a última; este uso pretende diferenciar os acoplamentos energéticos dos informacionais, que Wiener distinguiu, dado que aqueles descritos pela teoria da autopoiesis são sobretudo os de tipo energético (OLIVEIRA, 1993, 1996, 1999, 2004). 
- recupera claramente as pesquisas da Cibernética de $2^{a}$ ordem, acima expostas sinteticamente, em especial o trabalho de von Foerster e de o de Pask. Assim, como estes autores, entre outros, demonstraram, não existe uma correspondência ôntica entre aquilo que se descreve e aquilo que é descrito por um observador. Maturana e Varela dedicaram muita da sua investigação a estudar o mecanismo da observação humana e indicaram-nos também a multiplicidade causal de que ele decorre. O que conseguimos fazer com a capacidade observacional é lidar com as nossas representações mentais como se elas fossem entidades ontológicas; relacionandoas infinitamente entre si, dedutiva ou abdutivamente, conseguimos construir mundos fantásticos sem suporte ontológico, mas nos quais cremos veementemente. Estes estudos constituíram um duro golpe para as concepções cibernéticas de tipo cognitivista.

\section{Conclusões}

O que não podemos esquecer é que tudo o que se passa num observador, está sujeito ao primeiro princípio - aprender é viver - , dito de outro modo: a existência precede e auto-regula o pensamento, em organismos saudáveis. Isso não significa que aquilo que o pensamento produz é inimigo da vivência emotiva, afetiva, sensorial; pelo contrário, significa que lhes está subordinado. Por isso é que aquilo que lemos, que pensamos, que criamos mentalmente (como fórmulas matemáticas e sinfonias) nos pode marcar para sempre, do ponto de vista existencial, se for enquadrado na significação organizacional que construímos até então (e que constitui o nosso padrão). Pela mesma razão, muito do que lemos, pensamos e criamos mentalmente é ignorado no momento seguinte pelo nosso organismo, dado não ter sido registado como importante para a manutenção da nossa autopoiesis e/ ou das unidades compostas autopoiéticas que constituímos. A capacidade auto-observacional complexifica todo este processo de modo assaz interessante mas não se dispõe aqui de espaço para abordar tal questão.

Assim, o cérebro humano não é um computador que processa informações que lhe chegariam por input, processamento que ocorreria a partir das representações internas que lhe foram programadas. O cérebro humano existe como parte de um corpo que actua autopoieticamente, de modo a manter o sentido que a sua existência possui para o organismo em causa. Tal tem sido especialmente estudado no que respeita à percepção visual; os desenhos e pinturas de Escher e Magritte, por exemplo, testemunham a actuação activa do observador naquilo que vêem representado nessas obras. Essa multiplicidade de leituras decorre das vivências que fomos tendo ao longo da vida, dos significados que Ihes atribuímos e como isso foi sendo metabolizado neurofisiologicamente em todo o nosso organismo (VARELA; THOMPSON; ROSCH, 1991).

Da capacidade observacional de unidades compostas pode resultar aprendizagem, quando o que acontece ao nível observacional se inscreve no nosso padrão auto-organizacional, reforçando-o, ou flexibilizando-o.

A maior parte dos atos educativos são de tipo observacional, mas podem produzir muito pouca aprendizagem no educando dado que a organização do educando é que especifica o que é pertinente para a sua organização, abrindose então estruturalmente para esses tipos de fenômenos, de modo a que o organismo do educando (onde se inclui a sua mente) possa aprender. O modo mais fácil de isso ocorrer é quando o educador (formal, não formal, ou informal) se $\operatorname{acop}(u)$ la estruturalmente com o educando, passando ambos a existirem como unidades compostas; por isso é que aprendemos muito mais com os amigos do que com os professores, por exemplo.

Convém também não esquecer que muito daquilo que observacionalmente podemos considerar como desordem, ou até ruído, para o educando, pode ser fonte de aprendizagem - aplicando aqui o princípio de von Foerster de order from noise - , dado que algo avaliado como estranho e perturbador para um observador/educador pode revelar-se fecundo para o mundo de sentido construído até então pelo educando. Não nos deveríamos nunca esquecer, enquanto educadores, que foi caindo que aprendemos a andar e balbuciando sons desarticulados que aprendemos a falar.

O contrário pode porém também ocorrer: informação transmitida de modo muito organizado e esquematicamente comunicada pode revelar-se inútil face a pessoas que estão habituadas a aprender em contextos múltiplos, como os adolescentes urbanos que lêem, vêem 
televisão e ouvem música ao mesmo tempo. A única maneira que possuímos de perceber em que mundos de significações vivem os educandos (nossos filhos, nossos maridos, amigos, professores, alunos, etc.) com os quais queremos comunicar, é passarmos a fazer parte desse mundo; para tal, é preciso que nos deixem nele entrar, e de seguida pode ser que nos sintamos lá bem, ou não. Caso consigamos este acop(u)lamento estaremos a construir mundos comuns, flexibilizando aqueles já existentes com as contributos que trazemos das nossas vivências em outras comunidades (OLIVEIRA, 2008).

\section{Referências}

ATLAN, Henri. L'Organisation Biologique et la Théorie de I'Information. Paris: Hermann, 1972.

ATLAN, Henri. Essai sur l'Organisation du Vivant. Paris. Seuil, 1979.

BATESON, Gregory. Steps to an Ecology of Mind. Nova York: Ballantine Books, 1972.

BATESON, Gregory. Mind and Nature. Nova York: Bantam Books, 1979.

MATURANA, Humberto; VARELA, Francisco. De Maquinas y Seres Vivos. Santiago do Chile: Ed. Universitária, 1972.

MATURANA, Humberto; VARELA, Francisco. Autopoiesis and Cognition: The Realisation of the Living. Nova York: D. Reidel, 1980.

MINSKY, Marvin ; PAPERT, Seymour. Perceptrons: Massachussets: MIT Press, 1969.

MORIN, Edgar. Introduction à la Pensée Complexe. Paris; ESF éd., 1990.

MONOD, Jacques. O Acaso e a Necessidade. Mem Martins: Europa-América, 1970.

OLIVEIRA, Clara Costa. A Autopoiesis e as Ciências Humanas. Revista de Educação, Lisboa, v. 3, n. 2, p. 9-22, dez. 1993.

OLIVEIRA, Clara Costa. A Estrutura Epistemo-lógica dos Sistemas Autopoiéticos. Aprendizagem/ Desenvolvimento, Lisboa, v. 6, n. 21/22, p. 163-171, 1996.

OLIVEIRA, Clara Costa. A Educação Como Processo Auto-Organizativo: fundamentos teóricos para uma educação permanente e comunitária. Lisboa: Ed. Instituto Piaget, 1999.

OLIVEIRA, Clara Costa. A Importância da Interdisciplinareidade na História da Ciência: o caso da Cibernética e da Escola de Palo Alto. LaMusa Digital: revista digital de pensamiento, Albacete, n. 2, p.1.-.5., 2002

OLIVEIRA, Clara Costa. A Lógica da Observação: contributos para o esclarecimento do conceito de construtivismo. DiaCrítica: revista do Centro de Estudos Portugueses, Braga, n. 17, pt. 3, p. 339-349, 2003

OLIVEIRA, Clara Costa. Auto-Organização, Educação e Saúde. Coimbra: Ariadne, 2004.

OLIVEIRA, Clara Costa. Educação: pesquisa, complexidade e contemporaneidade. Reflexão e Ação, Santa Cruz do Sul, v. 16, n. 2, p.19.- 37, 2008.

PASK, Gordon. Uma Introdução à Cibernética. Coimbra: Arménio Amado ed., 1970. 
PRIGOGINE, Ilya; STENGERES, I sabelle. Sistema [verbete]. In: ENCICLOPÉDIA Einaudi. Lisboa: Impr. Nacional/ Casa da Moeda, 1993. V. 26.

VARELA, Francisco; THOMPSOM, Evan; ROSCH, Eleanor. The Embodied Mind: Cognitive Science and Human Experience. Cambridge: MIT, 1991.

VON FOERSTER, Heinz. On Self-organizing Systems and their Environment. In: YOUITS, M.G. ; CAMEROUS, S. (Org.). Self Organizing Systems. Londres: Pergamon Press, 1960. P. 36-75.

VON FOERSTER, Heinz. Principles of self-organization: in a socio-managerial context. In: ULRICH, H.; PROBST, G.J.B. (Ed.). Self-Organisation and Management of Social System. Berlim: Springer, 1984. P. 2-25.

WIENER, Norbert. Cybernétique et Société: I'usage humain des êtres humains. Paris: Deux Rives, 1971.

Recebido em agosto de 2009

Aprovado para publicação em setembro de 2009

\section{Clara Costa Oliveira}

Prof. Associada; CIED - Universidade do Minho (Portugal); email: claracol@iep.uminho.pt 